\title{
The correlation between response time and waiting time on patients' satisfaction at the emergency departement
}

\author{
Wasis Sapto Putro ${ }^{1}$, Sodikin ${ }^{2}$ \\ ${ }^{1,2}$ Nursing Department, Universitas Muhammadiyah Purwokerto, Indonesia
}

\section{ARTICLE INFO \\ Article history: \\ Received: August 9, 2020 \\ Revised: August 20, 2020 \\ Accepted: August 30, 2020}

Keywords:

Satisfaction, Response Time, Waiting Time

\begin{abstract}
Fast and accurate services are essential in the Emergency Departement (ED). Services in the emergency room will be hampered if it is are full of patients. If this is not managed well, the right services cannot be implemented. In turn, it will have a bad effect on patient satisfaction. To analyze the correlation between response time and waiting time with patient satisfaction during service at the Emergency Department of the Banyumas Regional General Hospital.This research is quantitative research. The sampling technique in this study used purposive sampling of 96 respondents. The statistical test used is the chi square test.Most respondents percieved the responding time in ER is fast; most of them also rated that the waiting time in ER is short. Most of them are also satisfied with ER services. The chi square test results in $\mathrm{p}$ value of $<0.05$ for each variable. It means there is a relationship between response time and waiting time with patient satisfaction during service at the Emergency Department of Banyumas Regional General Hospital.Response time and waiting time are related to patient satisfaction during service at the Emergency Department of Banyumas Regional General Hospital.
\end{abstract}

This work is licensed under a Creative Commons Attribution 4.0 International License.

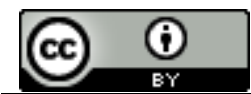

Corresponding Author:

Wasis Sapto Putro,

Department of Nursing, Universitas Muhammadiyah Purwokerto,

Jalan KH. Ahmad Dahlan PO BOX 202 Purwokerto 53182

Email: wasis.sp.79@gmail.com

\section{INTRODUCTION}

The Emergency Room (ER) is a service unit in a hospital that provides first-time services to patients with threats of death and disability in an integrated manner by involving various multidisciplinarity. ER services include nursing services aimed at emergency patients, namely patients who suddenly are in a critical condition or will lead to a serious and life threatening situation, if they do not get help quickly and accurately [1].

As one of the main sources of health services in hospitals, services in the ER have the aim of providing services that are fast, responsive and able to save patients' lives. Based on the Decree of the Minister of Health of the Republic of Indonesia [2] number 129 / Menkes / SK / II / 2008 regarding minimum hospital service standards, it states that there are several indicators of the quality of hospital services, especially in the Emergency Room, the response time is calculated from the time of arrival until they get a response from the Emergency Room staff with the service time needed by the patient to finish the emergency handling process [3].

In the service guidelines at Banyumas Hospital, ER services are carried out quickly and precisely by doctors on duty, nurses and other related teams. The length of waiting time for specialist consultation services, laboratory examinations, radiology, and diagnostic imaging services to meet the needs of patients and all types of examinations have to be in accordance with National standards, laws and regulations. According to the standard operating procedures for the Emergency Room in the Banyumas Regional General Hospital, the patient services at the Emergency Room within 6 hours must determine the following treatments needed: whether the patient is inpatient, outpatient or referred to another hospital.

In 2018, the emergency room visits in Banyumas hospital can be classified based on five groups of disease cases, namely, children's cases $13 \%$, surgical cases $14 \%$, obstetric cases $17 \%$, non-surgical cases $46 \%$, 
psychiatric cases $10 \%$. Meanwhile, in 2019 the first semester data on surgical cases was $14.3 \%$, non-surgical $45.9 \%$, obstetrics $17.3 \%$, people $9.9 \%$, while cases of children were $12.4 \%$. The data for emergency discharge patients during 2018 were around $74 \%$ inpatients, $26 \%$ outpatients, $0.11 \%$ referred to other hospitals. Based on these data, the most cases were non-surgical cases consisting of cases of internal disease and heart disease. During 2018 there were 22,298 emergency room visits, which means that the monthly average number was 1,858 or 61.09 patients per day, while in the first semester of 2019 the emergency room patients in Banyumas were 12,944 , which means its average number per month of 2,157 or 70 patients per day. In sum, there is an increase in EG visits in the first half of 2019 by $10 \%$.

Based on the results of observations and experiences of problems that occurred in the Emergency Room in the hospital, the response time and time in it still have not met the patient satisfaction standards. There was a need for service improvements in the ER to provide fast, responsive and safe services. In this way, the service will be more satisfying for the patients. The researchers believe there is a need to investigate and ascertain the factors that affect the delayed response time and waiting time in the ER, by presenting accountable data from the field and is expected to be a priority for hospital management, particularly addressing the problematic response time and waiting time in the ER services.

\section{RESEARCH METHOD}

Explaining This is a quantitative research by emphasizing its analysis on numerical data or the numbers obtained by statistical methods; it is in the framework of testing a hypothesis to know the significant relationship between the variables studied [4]. This research includes a correlational quantitative research, which is a study to determine the relationship between two or more variables without any attempt to influence these variables. The sample in this study was some patients treated in the Emergency Room at Banyumas hospital in December 2019. They were some of the ER patients who fit the inclusion criteria. The sample size in this study was determined using the Slovin formula, with a sample size of 96 respondents. The data analysis technique used in this research is the quantitative analysis. The statistical test used in this study is the ChiSquare test used to determine the correlation or relationship between two variables.

\section{RESULTS AND DISCUSSIONS}

\subsection{Univariate Analysis}

Table 1. The perception on time services, waiting time and patient satisfaction in the emergency room $(n=96)$

\begin{tabular}{lcc}
\hline Variable & Frequency & Procentage \\
\hline Responding time & & \\
$\quad$ Fast & 86 & $89.6 \%$ \\
$\quad$ Slow & 10 & $10.4 \%$ \\
Waiting time & & \\
$\quad$ Short & 76 & $79.2 \%$ \\
$\quad$ Long & 20 & $20.8 \%$ \\
Patients' satisfaction & & \\
$\quad$ Satisfied & 83 & $86.5 \%$ \\
$\quad$ Unsatisfied & 13 & $13.5 \%$ \\
\hline
\end{tabular}

Table 1. shows that most of the respondents $(89.6 \%)$ percieved the response time of the emergency service as fast and and only few (10.4\%) rated it as slow. The respondents who see that the waiting time for emergency service is short were $79.2 \%$ and the rest of $20.8 \%$ considered it too long. Most of the respondents $(86.5 \%)$ were satisfied with the ER services, and the rest thought it was not satisfying.

\subsection{Bivariate Analysis}

Table 2. Relationship between response time, waiting time and patient satisfaction

\begin{tabular}{|c|c|c|c|c|c|c|c|c|}
\hline & \multicolumn{4}{|c|}{ Patient satisfaction } & \multirow{2}{*}{\multicolumn{2}{|c|}{ Total }} & \multirow{3}{*}{ p-value } & \multirow{3}{*}{$\begin{array}{c}\text { Odd ratio }(95 \% \\
\text { CI })\end{array}$} \\
\hline & \multicolumn{2}{|c|}{ Satisfied } & \multicolumn{2}{|c|}{ Unsatisfied } & & & & \\
\hline & $\mathrm{f}$ & $\%$ & $\mathrm{f}$ & $\%$ & $\mathrm{n}$ & $\%$ & & \\
\hline \multicolumn{9}{|c|}{ Responding time } \\
\hline Fast & 77 & 92.8 & 9 & 69.2 & 86 & 89.6 & \multirow[t]{2}{*}{0,036} & \multirow[t]{2}{*}{$5.70(1.350-24.10)$} \\
\hline Slow & 6 & 7.2 & 4 & 30.8 & 10 & 10.4 & & \\
\hline \multicolumn{9}{|c|}{ Waiting time } \\
\hline Short & 69 & 83.1 & 7 & 53.8 & 76 & 79.2 & \multirow{2}{*}{0,040} & \multirow[t]{2}{*}{$4.22(1.23-14.49)$} \\
\hline Long & 14 & 16.9 & 6 & 46.2 & 20 & 20.8 & & \\
\hline
\end{tabular}


The table 2 shows the chi square test results obtained by a p value of $0.036(<0.05)$, which means that $\mathrm{Ha}$ is accepted. It means that there is a relationship between response time and patient satisfaction on the services in the Emergency Room of the hospital. The results of the chi square test showed that the odds ratio was 5.70, meaning that fast response percieved by respondent will increase 5.7 times for contributing to their satisfaction. The results of the chi square test obtained by a p value of $0.040(<0.05)$, meaning that Ha is accepted. Thus, there is a relationship between waiting time and patient satisfaction during service at the ER of the hospital. The chi square test also showed that the odds ratio was 4.22 , meaning that fast waiting time would give 4.22 times of opportunity for the patient satisfaction

\subsection{DISCUSSION}

\subsubsection{Response time for ER services in Banyumas Hospital}

Based on the data analysis, most of the respondents $(89.6 \%)$ rated the response time as fast, and only very few $(10.4 \%)$ considered it slow. Among the slow response rating of the patients, the perception for the nurses was only $2 \%$ while the one for the doctors was $8.4 \%$. This indicates that the response time of nurses is better than that of the doctor on duty. The problem is resulted from the lack of doctors on duty in ER, only one in a shift. When the number of patients arrive at the same time, then they have to wait long ( $>5$ mins) to get the doctor service. For nurses, there are 6 persons available for each shift. This makes their services more adequate. With this number even, particularly in the busy occassion, it is still not enough because some of them have to transfer the ER patients to the inpatient wards, which is quite far from ER. This may then make some patients have to wait longer (than $<5$ minutes). Various types of diseases and different patient conditions and the large number of concurrent patient visits to the ER have resulted in overcrowding in the ER.

\subsubsection{Waiting time of services at ER in Banyumas Hospital}

The value of long waiting time for ER is $20.8 \%$. It was made up of laboratory service components $(9.2 \%)$, transfer services to inpatient rooms $(7.2 \%)$, specialist consultation services $(4.4 \%)$, while radiology services $(0 \%)$. The longest one is the laboratory services. This is due to some delays in the process of samples examination. First, it is fact that not all samples taken are sent directly to the laboratory, because it has no special officer responsible for the delivery. Second, some samples which have been sent to the laboratory are not immediately examined by the in-charged personnel in the lab. Lastly, the delay is also found in the result delivery to ER; it is not not immediately reported or sent to the ER. Transfer services for patients to inpatients are responsible for 7,2\% of the slow services. Again, the number of person is also the key problem. There is only a transporter per shift, which is certainly hard to cover the daily patients in ER. There are more than 70 patients coming to ER. Besides, there is only manual tranporting vehicle available, which needs more time and energy to bring the people from ER to the wards. The hospital does not have any electric transporter. ER installation, in fact, is quite far awal from the inpatient wards. Those are the problems of patient transfer from ER [5].

Another aspect contributing to the slow service is specialists consultation service $(4.4 \%)$. It is due to the delay of the specialist in giving his/her prognosis based on the data provided by the doctor on duty. For this, an agreement should be made between the specialists and the doctors on duty, so the services can be done well. In a certain situation, the data should be taken to another specialist if the first consultant fails to serve in a certain period of time, which is agreed and established by the hospital as part of the service procedure. A good point is seen in radiology services. It is considered a fast service ( $0 \%$ for slow). This is supported by beneficial situations. The radiology is located very close to the ER. Besides, there is a direct electronic connection to the emergency room. The result of X-rays and its readings for emergency cases can be delivered directly to the radiologist online. These give the radiology service positive values.

\subsubsection{Patient satisfaction on the ER service in Banyumas Hospital}

Based on the data, it is proved that most respondents were satisfied with the ER services, as it is seen in the perception of 83 respondents $(86.5 \%)$. However, from the accummulation points of the response time and waiting time factors, it is still not very good. It is still below $90 \%$. According a service will be considered satisfactory if it can meet the customers' needs and expectations. The patient satisfaction is an important basis in measuring the quality of service. It is is dependent much on the performance of the health care provider.

\subsubsection{The relation of response time with patient satisfaction on the ER service in Banyumas Hospital}

The chi square test obtained a p value of $0.036(<0.05)$, meaning that Ha was accepted. It can be said that there was a relationship between response time and patient satisfaction on the ER service. This shows that the 
response time of doctors and nurses in providing services will determine the level of patient satisfaction. As it is mentioned previously, the response time of the doctor on duty needs to be faster, so that their satisfaction rate will increase. It is necessary to find the right solution. It is also the case with the obstacle to the response time of the nurses. They should be always available to serve in ER, and are not busy with other tasks other than their main function. The speed in providing services to patients in the ER determines the achievement of patient satisfaction levels. The results of this study are in line with the results of other Jaya's studies showing that there is a relationship between response time and patient satisfaction in the ER [6]. This, it is very conclusive that there is a significant relationship between the two variables, which means that the response time has a significant effect on patient satisfaction in the ER services.

\subsubsection{The relationship between waiting time and patient satisfaction on ER service in Banyumas Hospital}

Based on the result of chi square test, with a p value of $0.040(<0.05)$, it means that Ha is accepted. There is a relationship between waiting time and patient satisfaction on ER service in the hospital. The long waiting time will certainly make the patient dissatisfied. There are still $20.8 \%$ of ER patients percieving that waiting time is too long. There should be some improvements in laboratory services, transfers patients to inpatient rooms and specialist consultation. The waiting time for a health service plays a role in determining the rate of patient satisfaction. This is in line with another study, proving that there is a significant relationship between registration waiting time and patient satisfaction [7].

\section{CONCLUSION}

Based on the data analysis, it can be concluded that 1) most of the respondents $(89.6 \%)$ considered that the response time of ER services is fast, 2) among the poor response time, the doctors' service is responsible for $8.4 \%$, and the nurse is $2 \%, 3)$ most of the respondents $(79.2 \%)$ percieved that the waiting time for ER service is short, 4) among the long waiting time services, the contributors are laboratory $(9.2 \%)$, transfer of patients $(7.2 \%)$ and, specialist consultation $(4.4 \%), 5)$ most of the respondents are satisfied with the service, 6) the variables of response time and waiting time are proved to have a relationship with the patients' satisfaction.

\section{Acknowledgements}

The authors surely believe that without the helps and also supervisioSSn from many parties, this study is impossible to do. Thus, we want to extend our grateful thanks to Dr. Dani Esti Novia, who has provided the facilities in accessing the data from the hospital. My personal biggest appreciation goes to Mr. Sodikin, M.Kes, who has always guided me in conducting the research in the field, and also in writing its report. I also send my deep appreciation to many others in the faculty.

\section{REFERENCES}

[1] Musliha, Keperawatan Gawat Darurat, Yogyakarta: Nuha Medika, 2010.

[2] Menkes RI, "Keputusan Menteri Kesehatan RI Nomor 129/MENKES/SK/II/2008 tentang Standar Pelayanan Minimal Rumah Sakit," 2008. [Online].

[3] Haryantu, Nunuk and Sudaryanto, "Perbedaan Waktu Tanggap Tindakan Keperawatan Pasien Cidera Kepala Kategori I-V Di Instalasi Gawar Darurat RSUD Dr. Moewardi," Jurnal Berita Ilmu keperawatan, 2008.

[4] Sugiyono, Metode penelitian kuantitatif kualitatif, Alfabeta, 2011.

[5] Anjaryani, "Kepuasan Pasien Rawat Inap Terhadap Pelayanan Perawat di RSUD Tugurejo Semarang," Universitas Diponegoro Semarang, Semarang, 2009.

[6] A. G. Muninjaya, Manajemen Kesehatan, Jakarta: Penerbit Buku Kedokteran EGC, 2014.

[7] Iskandar, Metodologi Penelitian Pendidikan dan Sosial (Kuantitatif dan Kualitatif), Jakarta: GP Press, 2008. 